\title{
A New Balance Between IP and Antitrust
}

\author{
Mark A. Lemley
}

John M. Olin Program in Law and Economics

Stanford Law School

Working Paper No. 340

April 2007

This paper can be downloaded without charge from the Social Science Research Network Electronic Paper Collection:

http://ssrn.com/abstract $=980045$ 


\section{A NEW BALANCE BEWTEEN IP AND ANTITRUST}

Mark A. Lemley ${ }^{*}$

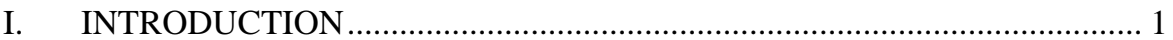

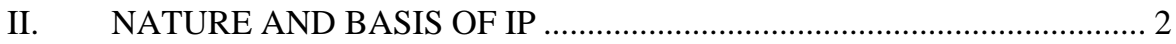

III. NATURE AND BASIS OF ANTITRUST LAW ......................................... 5

IV. THE INTERACTION BETWEEN IP AND ANTITRUST …...................... 9

A. Goals Not At Odds ............................................................................... 9

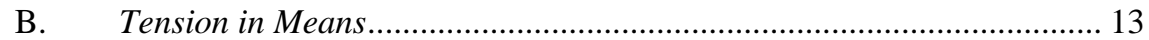

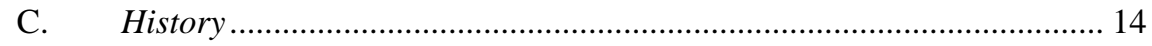

V. TOWARDS BALANCE IN DYNAMIC COMPETITION ....................... 17

\section{INTRODUCTION}

In this article, I introduce the interaction between intellectual property (IP) and antitrust law. ${ }^{1}$ I describe the ways in which these two important areas of government regulation are and are not in tension, and discuss the history of the relationship between these laws. I argue that IP and antitrust have cycled between over- and under-protection, and that we are currently (and mistakenly) conditioned to think of private property and private ordering as efficient in and of themselves, rather than as efficient only in the

* (C) 2007 Mark A. Lemley. William H. Neukom Professor, Stanford Law School; Of counsel, Keker \& Van Nest LLP. Thanks to William Comanor, Rose Hagan, Judge John Wiley, and participants in the conference in honor of Larry Sullivan for comments on an earlier draft.

1. This article is derived from Chapter 1 of 1 HERBERT HOVENKAMP, MARK D. JANIS, \&

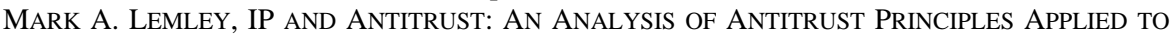
INTELLECTUAL PROPERTY LAW (1st ed. 2001 \& Supp. 2007), but I have made substantial changes and introduced new arguments for which my co-authors should not be held responsible. 
context of robust market competition. Further, I argue that antitrust can serve the goals of innovation and dynamic efficiency directly in circumstances in which competition, not monopoly, serves as a spur to innovation. The goal of the IP and antitrust laws should be to seek a robust balance between competition and monopoly in the service of dynamic efficiency. When IP laws are strong, antitrust laws should also be strong, and vice versa.

\section{NATURE AND BASIS OF IP ${ }^{2}$}

The concept of property is well understood in Western society. It is among the oldest institutions of human civilization. People may own real property and tangible objects. The common law and the criminal law protect private property from interference by others. The Fifth Amendment to the U.S. Constitution protects private property against takings by the government without just compensation. The philosophical bases for protection of private property are well-entrenched in our culture: as flowing naturally from mixing labor with Nature, as an incentive for discovery, as essential to personhood, and as a foundation for an ordered economic system.

All justifications for IP protection, whether based in economics or morality, must contend with a fundamental difference between ideas and tangible property. Tangible property-whether land or chattels-is composed of atoms, physical things which can occupy only one place at any given time. This means that possession of a physical thing is necessarily "exclusive"-if one person has it, no one else does. Indeed, the core of the Western concept of property lies in the right granted to the "owner" of a thing or a piece of land to exclude others from certain uses of it. Settled ownership rights in land and goods prevent both disputes over who can use the property for what purpose and the overuse of property that would result if everyone had joint access to it.

Ideas, though, do not have this characteristic of excludability. If one person who knows a particular piece of information tells it to another, the teller does not give up the information. Rather, they both possess it. The fact that the possession and use of ideas is largely "non-rivalrous" is critical to IP theory, because it means that the traditional economic justification for tangible property does not fit IP. There is no danger of overusing or overdistributing an idea, and no danger of fighting over who gets to use it, in the state of nature. Everyone can use the idea without diminishing its value.

\footnotetext{
2 Those with even a minimal background in IP and antitrust can safely skip Parts II and III.
} 
IP theorists have therefore looked beyond real property theory to justify exclusive rights in ideas. There are a number of alternate explanations for IP protection. The principal basis for IP protection in the United States is the utilitarian or economic incentive framework. That is, IP in the United States is fundamentally about incentives to invent and create. Both the United States Constitution and judicial decisions seem to acknowledge the primacy of incentive theory in justifying IP. The Constitution expressly conditions the grant of power in the patent and copyright clause on a particular end, namely "to Promote the Progress of Science and useful Arts." ${ }^{3}$ As the Supreme Court explained in the landmark case of Mazer v. Stein:

The copyright law, like the patent statutes, makes reward to the owner a secondary consideration. However, it is intended definitely to grant valuable, enforceable rights to authors, publishers, etc., without burdensome requirements: 'to afford greater encouragement to the production of literary [or artistic] works of lasting benefit to the world.'

The economic philosophy behind the clause empowering Congress to grant patents and copyrights is the conviction that . . . [it] is the best way to advance public welfare through the talents of authors and inventors in "Science and useful Arts." Sacrificial days devoted to such creative activities deserve rewards commensurate with the services rendered. ${ }^{4}$

To understand why the Framers thought exclusive rights in inventions and creations would promote the public welfare, consider what would happen absent any sort of IP protection. Invention and creation require the investment of resources - the time of an author or inventors, and often expenditures on facilities, prototypes, supplies, etc. In a private market economy, individuals will not invest sufficiently in invention or creation unless the expected return from doing so exceeds the cost of doing so- that is, unless they can reasonably expect to make a profit from the endeavor. To profit from a new idea or a work of authorship, the creator must be able either to sell it to others for a price, or to put it to some use that provides her with a comparative advantage in a market. ${ }^{5}$

But ideas (and writings, for that matter) are notoriously hard to control. Even if the idea is one that the creator can use herself, for example to boost

3. U.S. CONST. art. I, § 8, cl. 8.

4. Mazer v. Stein, 347 U.S. 201, 219 (1954) (citations omitted).

5. The latter may occur, for example, where an idea for a more efficient machine is used to reduce the cost of producing goods, allowing the owner of the idea to compete more effectively in selling those goods. 
productivity in her business, she will reap a reward from that idea only to the extent that her competitors don't find out about it. A creator who depends on secrecy for value therefore lives in constant peril of discovery and disclosure. Competitors may steal the idea through industrial espionage or learn of it from an ex-employee. They may be able to figure it out by watching the creator's production process, or by examining the products she sells (a process known as "reverse engineering."). Finally, they may come upon the idea on their own, or discover it in the published literature. In all of these cases, the secrecy value of the idea will be irretrievably lost.

The creator who wants to sell her idea is in an even more difficult position. Selling information requires disclosing it to others. Once the information has been disclosed outside a small group, however, it is extremely difficult to control. Information has the characteristics of what economists call a "public good"-it may be "consumed" by many people without depletion, and it is difficult to identify those who will not pay and prevent them from using the information. ${ }^{6}$ Once the idea of the intermittent windshield wiper is disclosed, others can imitate its design relatively easily. Once a book is published, others can copy it at low cost. It is difficult to exclude non-purchasers. Ideas and information can also be used by many without depleting the enjoyment of others. Unlike an ice cream cone, many can enjoy the concept of intermittent windshield wipers or a good story without diminishing the enjoyment of these creations by others.

If we assume that it is nearly costless to distribute information to others-an assumption that was once unrealistic but has become much more reasonable with the development of the Internet-it will prove virtually impossible to charge for information over the intermediate run in the absence of some property right in that information. If the author of a book charges more than the cost of distribution in hope of recovering some of her expenditures in writing the work, competitors will quickly jump in to offer the book at a lower price. Competition will drive the price of the book towards its marginal cost-in this case the cost of producing and distributing one additional copy. In this competitive market, the author will be unable to recoup the fixed cost of writing the book. More to the point, if this holds generally true authors may be expected to leave the profession in droves, since they cannot make any money at it. The result, according to

6. Kenneth J. Arrow, Economic Welfare and the Allocation of Resources for Invention, in THE RATE AND DiRECTION OF INVENTIVE ACTIVITY: ECONOMIC AND SOCIAL FACTORS 609, 61416 (Richard R. Nelson, ed., 1962). 
economic theory, is an underproduction of books and other works of invention and creation with similar public goods characteristics. ${ }^{7}$

By contrast, markets for pure private goods, such as ice cream cones, feature exclusivity and "rivalrous" competition-the ice cream vendor provides the good only to those who pay the price, and the consumer certainly depletes the amount of the good available to others. Thus, the market system provides adequate incentives for the creation of ice cream cones because sellers can exact their cost of production and the value of the product is fully enjoyed by the purchaser.

In the case of other public goods, such as national defense (and most lighthouses), society avoids the underproduction that would result from leaving it to the market by having the government step in and pay for the public good. For a variety of valid reasons, our legal system has not gone that route with information. Instead, government has created IP rights in an effort to give authors and inventors control over the use and distribution of their ideas, and therefore encourage them to invest efficiently in the production of new ideas and works of authorship. Thus, the economic justification for IP lies not in rewarding creators for their labor, but in assuring that they (and other creators) have appropriate incentives to engage in creative activities.

\section{NATURE AND BASIS OF ANTITRUST LAW}

Antitrust law protects competition and the competitive process by preventing certain types of conduct that threaten a free market. For example, antitrust prohibits competitors from agreeing on the price they will charge consumers. It prohibits certain "predatory" practices designed to exclude competitors from the market, and it places certain limits on the behavior of firms with market power. The guiding principle of modern antitrust law is that competition is generally desirable in order to achieve economic efficiency, though other more "populist" goals are often articulated. $^{8}$

Competition is good for a variety of reasons. Basic economics teaches that firms in competition will produce more and price lower than

7. See, e.g., F.M. SCHERER, INDUSTRIAL MARKET STRUCTURE AND ECONOMIC PERFORMANCE 444 (2d ed. 1980) ("If pure and perfect competition in the strictest sense prevailed continuously ... incentives for invention and innovation would be fatally defective without a patent system or some equivalent substitute.”). Scherer goes on to note, however, that natural market imperfections may give advantages to first movers, reducing the need for IP protection. Id. at $444-45$.

8. On the dominance of efficiency over other rationales for antitrust, see HERBERT HOVENKAMP, ANTITRUST ףף 100-113 (2d ed. 1993). 
monopolists. Monopolists not only take money away from consumers by raising prices, but they impose a "deadweight loss" on society by reducing their output below the level which consumers would be willing to purchase at a competitive price. Monopoly has other problems as well. It inherently reduces consumer choice, and monopolists have fewer incentives to innovate than do competitive firms because much of the profit from any innovation will simply steal profits from the monopolist's prior products.

Congress passed the first federal antitrust statute in 1890 . The Sherman Act, as the statute is called, was a reaction to populist pressure on Congress to do something about the "trusts" that had come to dominate the American business landscape. The Sherman Act granted broad powers to government to break up trusts and other conspiracies in restraint of trade. The Sherman Act is still in force today; it provides in part:

Every contract, combination in the form of trust or otherwise, or conspiracy, in restraint of trade or commerce among the several States, or with a foreign nation, is declared to be illegal. . . .

Every person who shall monopolize, or attempt to monopolize, or combine or conspire with any other person or persons, to monopolize any part of the trade or commerce among the several States, or with foreign nations, shall be deemed guilty of a felony ...

By their terms, these laws are broad indeed. In some sense, every contract necessarily restrains trade since it forecloses options that were once open. Under the literal terms of section 1, employment contracts and sales contracts might be considered antitrust violations. In practice, courts quickly gave the Sherman Act a more restrictive interpretation. The Supreme Court read section 1 as prohibiting only unreasonable restraints of trade. ${ }^{10}$ Much antitrust jurisprudence in the last century has attempted to delineate reasonable and unreasonable restraints of trade.

The courts also limited the reach of section 2, to ensure that successful businesses would not be punished because of their success. Since the antitrust laws provide for felony criminal punishments, private trebledamage actions and injunctions, and plaintiffs' attorneys' fees, the possibility of over-deterring legitimate business conduct is a real concern. To avoid this problem, courts have distinguished between possessing a monopoly and actively acquiring or maintaining a monopoly through anticompetitive conduct. Section 2 prohibits only the latter.

9. 15 U.S.C. $\S \S 1-2(2000)$.

10. See Standard Oil Co. of N.J. v. United States, 221 U.S. 1 (1911). 
In 1914, in response to what it perceived as lax judicial enforcement of the Sherman Act, Congress passed the Clayton Act. ${ }^{11}$ The Clayton Act contains a number of specific provisions that served to expand the reach of the antitrust laws. In particular, section 3 of the Clayton Act enumerates and prohibits certain types of agreements that are now also included within the general scope of section $1 .^{12}$

The Clayton Act was amended in 1950 to prohibit certain types of mergers. Section 7 of the Clayton Act prohibits mergers and acquisitions (of a corporation, stock, or assets) where "the effect of such acquisition may be substantially to lessen competition or to tend to create a monopoly" in "any line of commerce . . . in any section of the country."13

Thus, the antitrust laws prevent businesses from acting anticompetitively in three principal ways:

Monopolization. It is not illegal to have a monopoly. However, monopolists and firms in the process of acquiring market power are subject to greater scrutiny of their behavior than other firms. A monopolist violates section 2 if it has "market power" (defined as the power to raise prices or exclude competition in a relevant market) and engages in anticompetitive conduct designed to maintain or extend that power. ${ }^{14}$ Over time, courts have identified several anticompetitive practices and the circumstances in which they are actionable. ${ }^{15}$ A company may also be guilty of attempted monopolization if it intends to monopolize a market, engages in anticompetitive conduct, and has a "dangerous probability" of successful monopolization. ${ }^{16}$

To find that a defendant has monopolized a market, the court must first define the relevant market. Specifically, the court must identify a product or set of products and a geographic region in which the product is sold. Controlling such a market will allow a monopolist to raise prices without losing customers to competitors from outside the market. The definition of a relevant market and the analysis of power in that market are both

11. Clayton Act, ch. 323, § 7, 38. Stat. 730, 731-32 (1914) (current version at 15 U.S.C. §§ 12-27, 29 U.S.C §§ 52-53 (2000)).

12. 15 U.S.C. $\S 14(2000)$.

13. Id. § 18.

14. See generally HovenKAMP, supra note 7, III \& IIIA Chs. 6-8.

15. For a detailed discussion of these concepts, see 1 HOVENKAMP ET AL., supra note 1 , Chs. 10-13. In particular, chapter 10 discusses the general prerequisites for a section 2 monopolization claim. Chapter 11 examines claims based on the acquisition or enforcement of IP rights. Chapter 12 discusses claims based on innovation or design changes that disadvantage competitors. Chapter 13 focuses on claims based on a unilateral refusal to license an IP right.

16. See, e.g., Spectrum Sports, Inc. v. McQuillan, 506 U.S. 447, 456 (1993). 
extremely complex questions. A good deal of legal and economic work has gone into the attempt to define exactly what constitutes market power. ${ }^{17}$

Agreements. Courts have identified two basic types of agreements that may restrain trade-agreements among competitors (called "horizontal restraints") ${ }^{18}$ and agreements between buyers and sellers (called "vertical restraints"). ${ }^{19}$ Vertical restraints are generally less threatening to competition than horizontal restraints. With the exception of vertical minimum price fixing (or "resale price maintenance"), courts evaluate vertical restraints under the "rule of reason." Under the rule of reason, courts balance the anticompetitive harms of a restraint against its procompetitive benefits. Only those restraints which produce harms in excess of benefits to competition are deemed unreasonable. ${ }^{20}$

Horizontal restraints are more troubling because they may allow the participants to create a cartel, which can then behave anti-competitively, much as a monopolist would. At first, most agreements between competitors were deemed illegal per se, without any necessity for a weighing of harms and benefits to competition. Today, the Supreme Court has retreated from that position, recognizing that certain agreements among competitors may be efficient and pro-competitive. Most horizontal restraints are now judged under the rule of reason. Only certain forms of "naked" agreements to fix prices or divide territories remain illegal per se. ${ }^{21}$

Mergers and Acquisitions. Section 7 of the Clayton Act is intended to catch monopolies "in their incipiency." Because of this, the standard for

17. For a more detailed discussion of this issue, see IIA HERBERT HOVENKAMP ET AL., ANTITRUST LAW: AN ANALYSIS OF ANTITRUST PRINCIPLES AND THEIR APPLICATION, Ch. 5 (2d ed. 2000). law.

18. See XI-XIII id. Chs. 19-22 for a general discussion of horizontal agreements in antitrust

19. Actually, the term "vertical restraints" refers to a whole class of transactions between companies in a vertical relationship in the chain of distribution, including dealers, franchisors, distributors, resellers, etc. On vertical agreements in antitrust law generally, see VI, VIII-XI id. Chs. 14, 16, 17-18.

20. For an in-depth discussion, see 1 HovENKAMP ET AL., supra note 1, Chs. 20-25. Chapter 20 discusses the general prerequisites for a vertical section 1 claim, while the next chapter discusses claims based on tying and exclusive dealing. Chapter 22 examines claims based on package or blanket licensing and block-booking. Chapter 23 explains claims based on the nature of the royalty provision and chapter 24 discusses resale price maintenance and vertically-imposed non-price restraints. Chapter 25 focuses on "grantback" clauses in IP licenses and chapter 26 reviews non-competition covenants.

21. For a comprehensive discussion of horizontal restraints, see 1 HOVENKAMP ET AL., supra note 1, Chs. 30-36. Chapter 30 discusses the basic prerequisites for a horizontal section 1 claim and Chapter 31 discusses price restraints in horizontal licenses. The following chapter examines output limitation agreements. Chapter 33 then focuses on horizontal market division agreements. Chapter 34 discusses cross-licensing of IP and patent pools. Chapter 35 explains standard-setting organizations and Chapter 36 discusses joint ventures. 
proving the existence of market power is significantly lower in the case of a merger than in a section 2 monopolization claim. If a merger would substantially lessen competition in a relevant market, the courts may prohibit it. As with most other areas of antitrust law, however, courts are usually willing to consider a merger's potential benefits to competition in deciding whether it should be prevented. ${ }^{22}$

Most merger enforcement takes place at the Antitrust Division of the United States Department of Justice and at the Federal Trade Commission ("FTC"). The Hart-Scott-Rodino Act of 1976 requires companies to file a statement with the division and the FTC and to seek approval for mergers over a certain size. ${ }^{23}$ If the division or the FTC determines that a merger will restrain competition, it can challenge the merger in court before the merger takes place. ${ }^{24}$

\section{THE INTERACTION BETWEEN IP AND ANTITRUST ${ }^{25}$}

\section{A. Goals Not At Odds}

The complex interaction between antitrust and IP law arises out of these basic principles. Granting authors and inventors the right to exclude others from using their writings and ideas necessarily limits the diffusion of those ideas, and so prevents people from benefiting from them. In economic terms, IP rights prevent competition in the sale of the particular work or invention covered by the IP right, and therefore may allow the IP owner to raise the price of that work above the marginal cost of reproducing it. Indeed, in order for the IP laws to succeed in giving authors and

22. For an analysis of mergers in antitrust law generally, see IV-V HovENKAMP ET AL., supra note 16, Chs. 9-10 (rev. ed.), Chs. 11-12. For a discussion of mergers in the IP arena, see generally 1 HOVENKAMP ET AL., supra note 1, Chs. 14, 36. Chapter 14 covers acquisitions of IP rights and chapter 36 focuses on joint ventures subject to section 7 analysis.

23. 15 U.S.C. § $18 a(a)(2000)$.

24. 15 U.S.C. § $18 \mathrm{a}(\mathrm{f})(2000)$

25. Among the voluminous literature on the overlap between IP and antitrust law, See COMPETITION POLICY AND INTELleCtuAl PROPERTY RIGHTS IN THE KNOWLEDGE-BASED ECONOMY (Robert D. Anderson \& Nancy T. Gallini eds., 1998); WARD BOWMAN JR., PATENT AND ANTITRUST LAW: A LEGAL AND ECONOMIC APPRAISAL (1973); William F. Baxter, Legal Restrictions on Exploitation of the Patent Monopoly: An Economic Analysis, 76 YALE L.J. 267 (1966); Richard M. Buxbaum, Restrictions Inherent in the Patent Monopoly: A Comparative Critique, 113 U. PA. L. ReV. 633 (1965); Louis Kaplow, The Patent-Antitrust Intersection: A Reappraisal, 97 HARV. L. REV. 1813 (1984); Tracy R. Lewis \& Dennis Yao, Some Reflections on the Antitrust Treatment of Intellectual Property, 63 ANTITRUST L.J. 603 (1995); Willard K. Tom \& Joshua A. Newberg, Antitrust and Intellectual Property: From Separate Spheres to Unified Field, 66 ANTITRUST L.J. 167 (1997). 
inventors an incentive to create, the law must give them at least some power over price, though not always monopoly control. This means that in many cases fewer people will buy the work than if it were distributed on a competitive basis, and they will pay more for the privilege.

By contrast, a fundamental principle of our economic system is the proposition that free market competition will best ensure an efficient allocation of resources in the absence of a market failure. ${ }^{26}$ Antitrust law serves the goal of competition by ensuring that markets are not unfairly dominated by a single firm, and by making sure that putative competitors do not collude to avoid the effects of competition. In this limited sense, then, IP rights appear to run counter to free market competition: They limit the ability of competitors to copy or otherwise imitate the intellectual efforts of the first author or inventor. The existence of an IP right may enable those possessing such an exclusive right to charge monopoly prices or to otherwise limit competition, such as by controlling the use of the idea in subsequent products.

Because IP rights impose costs on the public, the IP laws can be justified by the public goods argument only to the extent that the laws on balance encourage enough creation and dissemination of new works to offset those costs. One of the reasons that IP rights are limited in scope, duration, and effect, is precisely in order to balance these costs and benefits. For example, the limited term of IP rights ensures that inventions will be freely available after a fixed term. The key to economic efficiency lies in balancing the social benefit of providing economic incentives for creation and the costs of limiting the diffusion of knowledge.

This balancing approach sets the stage for IP law's interaction with antitrust. A simplistic assessment of this interaction might proceed as follows: IP rights are monopolies, and antitrust is designed to prevent monopoly, so the two laws are in conflict. Indeed, on several occasions in U.S. history courts and scholars seem to have taken precisely this approach. $^{27}$ In fact, however, both premises are wrong, or at least

26. A market failure occurs when, owing to the inherent characteristics of the market, too much or too little will be produced or consumed.

27. See, e.g., United States v. Westinghouse Elec. Corp., 648 F.2d 642, 646 (9th Cir. 1981) ("[o]ne body of law creates and protects monopoly power while the other seeks to proscribe it."). Further back in history, the principle that patents (or indeed all IP rights) were "monopolies" of which antitrust law should be especially wary was taken for granted. See, e.g., Henry v. A.B. Dick Co., 224 U.S. 1, 27 (1912) (patent "is a true monopoly”); WiLliam C. RoBinson, THE LAW OF PATENTS FOR USEFUl INVENTIONS 67 (Boston, Little, Brown, and Co. 1890); Hon. Giles S. Rich, Are Letters Patent Grants of Monopoly?, 15 W. NEW ENG. L. REV. 239 (1993) (reviewing the history of the debate over whether patents are monopolies). For more detail, see also 1 HOVENKAMP ET AL., supra note 1, Ch. 4. 
oversimplified. IP rights do not ipso facto confer monopoly power. While they do permit product differentiation, and sometimes give the owner power over price, there is a vast difference between an exclusive right and the sort of economic monopoly that is the concern of antitrust law. Indeed, the vast majority of patented products and processes are commercial failures. And even where a patented (or particularly a copyrighted or trademarked) product is successful in the marketplace, it normally competes for the attention of consumers with many other products, some themselves protected by IP rights. To choose just one example, virtually all mystery novels are copyrighted, yet no one could seriously claim that any one mystery novel held a monopoly in a relevant economic market.

At the same time, it is too facile to say that antitrust law forbids monopoly. While it is certainly true that the goal of antitrust is to promote competition, the law has never made monopoly itself illegal. Rather, it has concerned itself with particular sorts of anticompetitive conduct designed to achieve market power. By contrast, a company that achieves and maintains a monopoly without engaging in such conduct will not run afoul of the antitrust law. ${ }^{28}$ As Judge Hand put it:

A single producer may be the survivor out of a group of active competitors, merely by virtue of his superior skill, foresight and industry. In such cases a strong argument can be made that, although, the result may expose the public to the evils of monopoly, the Act does not mean to condemn the resultant of those very forces which it is its prime object to foster ... The successful competitor, having been urged to compete, must not be turned upon when he wins. ${ }^{29}$

Indeed, when one departs from the static view of markets and takes a longer-run approach, it is even plausible that IP and the antitrust laws share a common goal. As Ward Bowman explains:

In terms of the economic goals sought, the supposed opposition between these laws is lacking. Both antitrust law and patent law have a common central economic goal: to maximize wealth by producing what consumers want at the lowest cost. In serving this common goal, reconciliation between patent and antitrust law involves serious problems of assessing effects, but not conflicting purposes. Antitrust law does not demand competition under all circumstances. Quite properly, it permits monopoly

28. See generally X HOVENKAMP ET AL., supra note 16, ๆ 617.

29. United States v. Aluminum Co. of Am., 148 F.2d 416, 430 (2d Cir. 1945). 
when monopoly makes for greater output than would the alternative of an artificially fragmented (inefficient) industry. The patent monopoly fits directly into this scheme insofar as its central aim is achieved. It is designed to provide something which consumers value and which they could not have at all or have as abundantly were no patent protection afforded. ... .

$\ldots$

The goal of both antitrust law and patent law is to maximize allocative efficiency (making what consumers want) and productive efficiency (making these goods with the fewest scarce resources). In achieving this goal under either antitrust or patent law the detriment to be avoided is output restriction. This may arise from monopolization which diverts production from more urgent to less urgent use or from legal rules requiring inefficient methods of production. The evil then may be viewed as net output restriction after efficiency increases are accounted for. Both antitrust and patent law seek output expansion not output restriction. Competition deserves support insofar as it brings about this result. And so it is with patents. The temporary monopoly afforded by a patent, once a particular invention has come into being, will have all the outputrestrictive disabilities of any monopoly. The argument for patents is that without this temporary monopoly there would be insufficient profit incentives to produce the invention, and that because an invention is profitable only if consumers are willing to pay what the patentee charges, the consumers are therefore better off than they would be without the invention, even if they are charged "monopoly" prices. If this is so, a trade-off (some monopoly restraint for greater output in the long run) is in the interest of socially desirable resource allocation. An appraisal of alleged conflicts between antitrust law and patent law depends upon understanding the role of profits in providing the incentive for undertaking efficient production of those things consumers value. ${ }^{30}$

On this view, when viewed in context the two laws are not in conflict at all. Rather, they are complementary efforts to promote an efficient marketplace and long-run, dynamic competition through innovation. ${ }^{31}$

We can extend Bowman's point in an important dimension. The benefits of competition are not merely static - avoiding deadweight loss. Were that true, there would be a good case for the primacy of IP. In a wide

30. See Bowman, supra note 24, at 1-3. See also Paul Goldstein, The Competitive Mandate: From Sears to Lear, 59 CAL. L. REV. 873 (1971).

31. See, e.g., Atari Games Corp. v. Nintendo of Am., 897 F.2d 1572, 1576 (Fed. Cir. 1990) (patent and antitrust law "are actually complementary, as both are aimed at encouraging innovation, industry and competition.”). 
variety of industries, history has shown that the long-run benefits of innovation dwarf the benefits of competition for existing products. Ask yourself whether you'd rather pay monopoly price for an iPod or a competitive price for an eight-track tape player. ${ }^{32}$ In fact, however there is substantial economic evidence suggesting that competition itself may act as a greater spur to innovation than monopoly. ${ }^{33}$ In those industries and circumstances in which this is true, antitrust more directly serves the same goal as patent law. Both encourage innovation.

\section{B. Tension in Means}

Identifying complementary goals for the two laws does not end the inquiry, however. The opposite argument-that there is no tension between IP and antitrust law-is equally facile. Bowman is best understood as saying that both patent law and antitrust law are tools to be used in promoting wealth maximization. They are designed to be used together to achieve a certain result. However, they strive towards that result in ways that are often in tension. Antitrust law seeks to maximize efficiency by preventing monopolization or other forms of anticompetitive conduct. IP, while it does not generally create a monopoly, may in some cases permit or even encourage monopoly in order to give incentives for invention. That invention, in turn, may generate longer-term wealth gains to society.

There is room, therefore, for the patent and antitrust laws to coexist in the service of long-run, dynamic efficiencies. In this scheme, IP and antitrust sometimes do not overlap at all. Most copyright and trademark cases, for example, don't involve even a credible allegation of market power or anticompetitive conduct. Similarly, most antitrust cases don't involve IP.

This doesn't mean, however, that antitrust law does not or should not constrain the scope of IP rights. Just as it was too facile to assume that IP rights confer monopolies, it is also wrong to equate IP with real property and therefore to assume that it can never confer market power. ${ }^{34}$ IP rights

32 I am indebted to Judge John Wiley for this point.

33 Ken Arrow has long been associated with this position. See Arrow, supra note _. For a review of the economic evidence supporting this position, see Mark A. Lemley, Property, Intellectual Property, and Free Riding, 83 Tex. L. Rev. 1031 (2005).

34. The classic statement of the "no conflict" position is Judge Markey's opinion in Carl Schenck, A.G. v. Nortron Corp., 713 F.2d 782, 786 n.3 (Fed. Cir. 1983):

A patent, under the statute, is property. Nowhere in any statute is a patent described as a monopoly. . . That the property right represented by a patent, like other property rights, may be used in a scheme violative of antitrust laws creates "no conflict" between laws establishing any of 
are granted in unique goods, and in some respects patent law in particular gives patent owners rights far greater than any that would be granted by real property law. It is possible to use an IP right to obtain unwarranted market power or interfere with competition in a variety of ways, and antitrust law properly addresses conduct of that sort.

Further, if I am correct that competition, not just monopoly, can serve as a spur to innovation, the use of antitrust law to encourage innovation also exists in considerable tension with the use of IP rights to achieve the same end. If the law is to encourage innovation in a particular industry, it must choose among IP, antitrust, or some combination of the two to do so. This choice doesn't have to be universal; there is good reason to believe that IP rights work better in some circumstances and competition in others. ${ }^{35}$ But it does have to be made: IP and competition work towards the goal of innovation at cross purposes.

Where the two laws do come into contact, then, courts must reconcile the tension between them. In this limited set of cases, it bears recognizing that patents and other IP rights limit the reach of the antitrust laws. ${ }^{36}$ At the same time, antitrust constrains what a patentee can do with its patent. In particular, antitrust will be concerned not with the legitimate exercise of an IP right granted by the government, but with efforts to expand the scope of that right, either to new products, or temporally, or by conditioning access to the right on restrictions of competition. Efficient wealth maximization requires that a line be drawn between conduct that is permissible and that which is impermissible. Drawing that line is the hard work of both IP and antitrust law.

\section{History}

The history of the interaction between IP and antitrust law is long and complex. Several facts bear emphasis. First, the vast majority of the IP-

those property rights and the antitrust laws. ... It is but an obfuscation to refer to a patent as "the patent monopoly" or to describe a patent as an "exception to the general rule against monopolies." 35 See, e.g., Dan L. Burk \& Mark A. Lemley, Policy Levers in Patent Law, 89 Va. L. Rev. 1575 (2003).

36. As Ward Bowman explains,

The problem of assessing permissible output restriction under patent law is, in one important sense, different from that under antitrust law. The legal propriety of a basic patent monopoly has to be recognized. Consequently, evaluating whether certain patent licensing practices should be sanctioned will involve the proper scope of the legal monopoly. Is more being monopolized that what the patent grants, or is the practice merely maximizing the reward attributable to the competitive advantage afforded by a patent?

BowmAn, supra note 24, at 8. See also Louis Kaplow, The Patent-Antitrust Intersection: A Reappraisal, 97 HARV. L. REV. 1813 (1984). 
antitrust cases involve patents. While copyrights, trademarks and trade secrets have all produced antitrust issues at one time or another, the fundamental outlines of the law have been established in patent cases.

Second, not all of the cases that fit within the IP-antitrust rubric actually involved antitrust law at all. The doctrines of patent (and more recently, copyright) misuse serve many of the same purposes as antitrust law, and overlap substantially with antitrust rules.

Third, case law regarding the interaction is of relatively recent vintage. While one can find "abuse of patent" cases in England going back to $1600,{ }^{37}$ it is not until the early part of the $20^{\text {th }}$ Century that these issues began to receive significant attention. In part, of course, this is because antitrust law itself is of recent provenance-the Sherman Act was passed in 1890. But the modern nature of IP-antitrust cases also results from the growing importance of IP in an industrial and then an information economy.

Finally, the history of the intersection has been characterized by cycles of over- and under-enforcement, in which first antitrust and then IP is on the ascendancy while the other recedes into the background. This cyclical history has kept the two laws from settling into a healthy balance. Rather than antitrust and IP law working in tandem, so that more powerful IP rights are balanced by more detailed antitrust scrutiny, too often throughout history courts and scholars have simply vacillated between the two untenable positions rejected above: IP as property and IP as monopoly.

In the modern era, this cyclical history began in the first two decades of the Twentieth Century with what was arguably rather substantial overreaching by IP owners. Copyright owners sought to control the resale price of books by including a notice inside the book purporting to forbid resale. Movie exhibitors, who still held patents on film and projection equipment, sold projectors subject to the condition that the purchasers resell them only at a specified price, and that the projectors only be used with the licensor's patented film. Some courts had permitted such restrictions. ${ }^{38}$

These attempts to expand the traditional scope of IP rights beyond the first sale of the patented or copyrighted product triggered an antitrust backlash beginning in 1917 with Motion Picture Patents Co. v. Universal

37. See, e.g., LeWIS EDMUNDS, THE LAW AND PRACTICE OF LETTERS PATENT FOR InVENTIONS 7-8 (London, Stevens \& Sons 1890) (relating the case of Mompesson and Mitchell, who were stripped of their patents and imprisoned for abusing the patent granted to them in the early part of the Seventeenth Century).

38. See Heaton-Peninsular Button-Fastner Co. v. Eureka Specialty Co., 77 F. 288 (6th Cir. 1896) (permitting a patentee to condition the license of its patent, on the theory that since the patentee could refuse to license the patent at all, it should be able to impose whatever conditions it wished upon that license). 
Film Mfg Co. ${ }^{39}$ In that case, which concerned the movie projectors just mentioned, the court held that the patent owner had misused its patent by seeking to impose conditions on the license outside the scope of the patent right. ${ }^{40}$ In particular, the court was concerned with the company's effort to "tie" its film to its projectors, forcing purchasers who wanted the projectors to take the film as well. ${ }^{41}$ The court's objections to tying seemed to stem from concerns about price discrimination as well as concerns about expanding the scope of the patent grant to include products not covered by the patent. The court reacted by defining such conduct to be patent misuse, a new limitation on the scope of patent licenses based in fundamental patent policy.

Following the Motion Picture Patents case, restrictions on tying became a centerpiece of antitrust law governing patents. Both antitrust and misuse cases imposed successively tighter restraints on tying practices during the 1930s and 1940s. Significantly, this stronger role for antitrust coincided with a variety of judicial decisions weakening the patent right, most notably by imposing a high standard of "invention" as a condition of patentability. The heightened antitrust scrutiny during this period culminated in the Carbice and Mercoid cases. ${ }^{42}$ Those cases held that misuse of a patent was prima facie evidence of an antitrust violation, even absent proof of market power or anticompetitive effect, and that one could commit patent misuse by "tying" a patented machine to non-staple products (products with no commercial use except in connection with the patented machine).

Congress reacted to this restrictive trend in the antitrust law by passing the Patent Act of 1952. ${ }^{43}$ That Act circumscribed the doctrine of patent misuse by adding a new section, 271(d), which provided that certain specified activities did not constitute patent misuse. It also strengthened the patent system. During the 1950s, in the wake of the new statute, patent rights became stronger and antitrust correspondingly fell into relative obscurity. However, by the 1960s and 1970s, patents were once again in disfavor and antitrust had returned with full force. Most litigated patents were held invalid during this period. Further, obtaining an invalid patent

39. Motion Picture Patents Co. v. Universal Film Mfg. Co., 243 U.S. 502 (1917).

40. Id. at 518-519.

41. Id.

42. See Mercoid Corp. v. Mid-Continent Inv. Co., 320 U.S. 661 (1944) (Mercoid I); Carbice Corp. v. American Patents Dev. Corp., 283 U.S. 27 (1931).

43. S. Rep. No. 82-1979, at 1 (1952) (current version at 35 U.S.C. § 1-4 (2000)). 
could subject its owner to antitrust liability, ${ }^{44}$ as could attempting to enforce a patent ${ }^{45}$ or any of a number of different licensing practices. ${ }^{46}$

The pendulum swung back again beginning in 1981. The Court of Appeals for the Federal Circuit, created in 1982 to hear all patent cases, rapidly strengthened the rights of patent owners, increasing the percentage of patents held valid from $35 \%$ to $54 \% .{ }^{47}$ More recently, Congress and the courts have dramatically expanded the scope of copyrights and trademarks, and IP owners have embarked upon some of the same licensing practices that were condemned back in the early decades of the $20^{\text {th }}$ Century. The Reagan Administration expressly rejected the Antitrust Division's prior restrictive rules on IP licensing, and drastically reduced government antitrust enforcement across the board. And in 1988 Congress passed the Patent Misuse Reform Act, ${ }^{48}$ which further restricted the circumstances under which the misuse defense could be invoked.

It remains to be seen whether (or perhaps more appropriately, when) the pendulum will swing back away from the primacy of IP and towards antitrust. In the 1990s, the Antitrust Division and the Federal Trade Commission expressed renewed interest in IP issues, releasing Guidelines for the licensing of IP in 1995. ${ }^{49}$ A number of high-profile cases at the end of the last century and the beginning of this one suggested that antitrust law was awakening from its period of dormancy, although the change in administration in 2001 seemed to reduce at least the Antitrust Division to quiescence.

\section{TOWARDS BALANCE IN DYNAMIC COMPETITION}

The cyclical nature of the IP-antitrust interface is understandable, given the fact that the interests that drive the strengthening of one law also push toward weakening the other. But it is not desirable. The goal of both IP and antitrust as regulatory policy should be to balance the need for incentives to innovate against the need for robust competition. We need

44. See Walker Process Equip. v. Food Machinery \& Chem. Corp., 382 U.S. 172, 173 (1965).

45. See, e.g., Handgards, Inc. v. Ethicon, Inc., 601 F.2d 986 (9th Cir. 1979), cert. denied, 444 U.S. 1025 (1980).

46. In the 1970s, patent licensing was governed by the infamous "nine no-nos" identified by the Antitrust Division. For more detail, see Charles Rule, The Administration's Views: Antitrust Analysis After The Nine No-No's, 55 ANTITRUST L.J. 365 (1986).

47. See John R. Allison \& Mark A. Lemley, Empirical Evidence on the Validity of Litigated Patents, 26 AIPLA Q.J. 185 (1998).

48. Pub. L. No. 100-703, § 201, 102 Stat. 4674, 4676 (1988) (current version at 35 U.S.C. § 271(d)(4)-(5) (2000)).

49. The Fed. Antitrust Guidelines For the LiCENSING OF INTELLECTUAL ProP. (2002). 
both innovation and competition to achieve dynamic efficiency. IP laws should ideally encourage innovation up to the optimal level, but no further, because overly strong IP laws unduly interfere with competition and therefore reduce welfare unnecessarily. ${ }^{50}$ The same is true in reverse: overly aggressive competition law sometimes privileges static efficiency over innovation and therefore reduces long-term welfare. To this balance we must add another: too much emphasis on IP to encourage innovation may have the opposite effect, impeding innovation, while too much emphasis on competition in an effort to spur innovation may also prove counterproductive.

As I noted in the last section, the balance has at least until quite recently been tilted in favor of IP law and against antitrust law. There are some signs that this is changing-not yet in antitrust, where the courts have struck down even antitrust challenges against conduct by patent owners that is unquestionably anticompetitive, ${ }^{51}$ but in patent law, where the Supreme Court has intervened to reduce the power of patents in some significant respects. $^{52}$ There are also reasons to think the power of patents may shrink further in the next two years, as the Court decides the KSR case ${ }^{53}$ on the obviousness standard for patentability and as Congress considers proposals for patent reform.

Whatever the current tilt and likely direction of the pendulum, our goal needs to be a world in which strong IP rights are coupled with strong rather than weak antitrust enforcement, and weak IP rights are coupled with weak rather than strong antitrust enforcement. To accomplish this, we need to recognize the importance of both doctrines. I think that requires two changes to the ways we think about the problem today.

First, much of the current vogue for IP and against antitrust comes from a myopic view of private ordering. Since Adam Smith, the case for the efficiency of a market economy over central control has been clear. But of late, it has become all too common to substitute a rather different conclusion: not that free markets are efficient, but that private decisions are. Once that switch is made, it is easy to argue that we should respect the decisions of patent owners-private, profit-maximizing entities—and

50 In practice, of course, it is difficult to determine the optimal level of either IP or antitrust enforcement, and the courts must deal with approximations.

51. See, e.g., In re Tamoxifen Citrate Antitrust Litig., 466 F.3d 187, 212 (2d Cir. 2006); Valley Drug Co. v. Geneva Pharmaceuticals, Inc., 344 F.3d 1294 (11th Cir. 2003).

52. See eBay, Inc. v. MercExchange LLC, 126 S.Ct. 1837 (2006); Medimmune, Inc. v. Genentech, Inc., 127 S.Ct. 764 (2007).

53. Teleflex, Inc. v. KSR Int'l, Co., 119 Fed. Appx. 282 (2005), cert. granted, 75 U.S.L.W. 3262 (U.S. June 26, 2006) (No. 04-1350). 
devalue the contributions of courts and government antitrust agencies. But the idea that individual private decisions are socially efficient has little if anything to recommend it. Neither Adam Smith nor any other classical economist saw any reason to believe that an individual private actor would act in the public interest. Quite the contrary. ${ }^{54}$ The only reason that private decisions produce efficient results is that they are disciplined by the marketplace, so that the many greedy, short-sighted, and just plain stupid decisions businesses make every day end up hurting those businesses but not consumers, who can always turn to a smarter or better-informed rival. It is ironic indeed that advocates of private ordering at all costs have perverted Smith's lesson to argue that we don't need the discipline of a competitive market. Understood properly, private ordering requires vigorous antitrust enforcement.

Second, we must treat IP and antitrust law as equals. The current approach treats IP rights as having primacy within their established boundaries, and relegates antitrust to the role of policing departures from those boundaries. ${ }^{55}$ This is evident in a variety of Federal Circuit opinions, not only in the misuse context ${ }^{56}$ (where it is perhaps understandable) but in assessing fundamental questions such as the legality of conditional refusals to deal involving patents. ${ }^{57}$ While there is clearly logic to this frameworkthe grant of a patent must confer some rights on its owner that it would not have had in the absence of that grant, and antitrust should not interfere with those core rights - it is directly responsible for the cycles of over- and under-protection that have characterized the IP-antitrust interface. When patent rights get stronger, we want antitrust to get stronger to prevent abuses of the right; instead, it recedes, as it must in any system where its powers are determined by the bounds of the patent right. Similarly, when the patent owner's rights are narrowed, the antitrust "sea" floods in to fill the gap, even though the risk of monopolistic abuse has been reduced.

54. AdAM SMith, AN INQUiRY INTO THE NATURE AND CAUSES OF THE WEALTH OF NATIONS 145 (R.H. Campbell \& A.S. Skinner, eds., Claredon Press 1976) (1776) ("People of the same trade seldom meet together, even for merriment and diversion, but the conversation ends in a conspiracy against the public, or in some contrivance to raise prices.”).

55. See Joseph Scott Miller, Patent Ships Sail an Antitrust Sea, 30 SeAttle U. L. ReV. 395 (2007).

56. See, e.g., B. Braun Med., Inc. v. Abbott Labs, 124 F.3d 1419, 1426 (Fed. Cir. 1997)

The patent misuse doctrine, born from the equitable doctrine of unclean hands, is a method of limiting abuse of patent rights separate from the antitrust laws. The key inquiry under this factintensive doctrine is whether, by imposing the condition, the patentee has "impermissibly broadened the 'physical or temporal scope' of the patent grant with anticompetitive effect." (quoting Windsurfing Int'l, Inc. v. AMF, Inc., 782 F.2d 995, 1001 (Fed. Cir.1986).

57. See, e.g., In re Indep. Serv. Orgs. Antitrust Litig., 203 F.3d 1322 (Fed. Cir. 2000). 
The idea of antitrust as a supporter of innovation argues even more strongly for treating IP and antitrust as equals. On this view, both IP and antitrust are policy tools that can be used to encourage innovation and therefore promote dynamic efficiency. ${ }^{58}$ Which tool we use depends on the industry in question and the nature of the invention. Requiring one of these tools to defer to the other makes no sense, unless we conclude that one approach is always better than the other. And the evidence doesn't support that conclusion.

Creating this new, more equal balance will, I concede, create more cases of direct conflict between patent and antitrust, particularly during periods of expansive IP rights. ${ }^{59}$ It will also create gaps during periods of low protection, when patent owners are free to expand their rights by contract without antitrust interference. But those changes are the price we must pay to stop the incessant swinging of the pendulum, and to try to achieve the goals IP and antitrust share.

58 See, e.g., Gustavo Ghidini \& J.H. Reichman, Intellectual Property and Competition Law: The Innovation Nexus (2006).

59 This sort of balancing is one explanation for the European Court of Justice's approach in the Magill and IMS Health cases, which used antitrust law to override what in both cases was an illadvised application of IP protection. See Case C-418/01, IMS Health GmbH \& Co. OHG v. NDC Health Gmbh \& Co. KG, [2004] E.C.R. I-5039; RTE v. Commission (Magill), [1995] E.C.R. I743, [1995] 4 C.M.L.R. 718. The risk is that the European approach goes to the opposite extreme of the pendulum, giving antitrust primacy over IP rather than balancing the two. See Harry First, Microsoft and the Evolution of the Intellectual Property Concept, 2006 Wis. L. Rev. 1369, (EC approach "places intellectual property inside competition policy”). 